\title{
Sobrevoando histórias: sobre índios e historiadores no Brasil e nos Estados Unidos
}

Soraia Sales Dornelles*

Karina Moreira Ribeiro da Silva e Melo**

Resumo: As historiografias brasileira e norte-americana compartilham diversos aspectos quando o assunto é a questão indígena. Em ambas, as histórias dos grupos nativos modificaram as formas de produzir conhecimento sobre eles, criando e transformando políticas públicas. Jogos de influências complexos pautam as formas de lidar com os saberes sobre as relações interétnicas. Em muitos casos, tais saberes serviram como sustentáculo para a sobrevivência ou para o padecimento daqueles grupos. As trajetórias historiográficas, lá e cá, são repletas de convergências, divergências, dinamismo e complexidade política. Isto posto, o objetivo deste artigo é apresentar uma visão paralela dos dois processos de construção de discursos históricos sobre os índios e traçar, a partir daí, as agendas e possibilidades de contribuições mútuas.

Palavras-chave: Índios. História Indígena Brasileira. História Indígena NorteAmericana. Historiografia.

* Doutoranda em História Social (UNICAMP). Bolsista CNPq. Contato: soraiasdornelles@gmail.com.

** Doutoranda em História Social (UNICAMP). Bolsista CNPq.

Contato: karinaemelo@hotmail.com.

Anos 90, Porto Alegre, v. 22, n. 41, p. 173-208, jul. 2015 


\section{Introdução: sobrevoando os EUA}

O surgimento do campo de estudos que aborda aspectos históricos sobre os grupos nativos nos Estados Unidos pode ser identificado dentro do contexto da expansão para o Oeste, no século XIX, pautada pela ideia de um Destino Manifesto e pela concomitante profissionalização de disciplinas como História, Etnologia e Antropologia ${ }^{1}$.

Em maio de 1830, durante a presidência de Andrew Jackson, o Congresso americano aprovara o Indian Removal Act (Lei de Remoção dos Indios), que determinava que as terras indígenas poderiam ser compradas somente pelo Estado e permitia ao poder executivo negociar com os grupos do Sul, chamados de Cinco Tribos Civilizadas - Chickasaw, Choctaw, Muscogee-Creek, Seminole e Cherokee -, sua remoção para um território federal a oeste do rio Mississipi em troca de suas terras originais. Conforme a política anterior, de Thomas Jefferson, os nativos que se adaptassem ao modo de vida civilizado, isto é, voltado ao trabalho agrícola, poderiam viver ao leste do Mississipi e manter a autonomia de suas nações; caso não aceitassem a assimilação, poderiam ser punidos. Essas terras eram amplamente cobiçadas pelos colonizadores sulistas, que já as disputavam com os índios, principalmente na Geórgia, e, assim, apoiaram as mudanças propostas por Andrew Jackson. Algumas remoções ocorreram por meio de tratados que implicaram a venda ou troca de territórios. Outros grupos nunca firmaram acordos e foram perseguidos em longas guerras (McDONNELL, 1991, p. 06-19)2.

Enquanto isso, no Oeste, em estados mais antigos como o Texas, Novo México, Utah, Oregon, Califórnia e Washington, diversos grupos indígenas e colonos, de origem hispânica majoritariamente, mantinham relações de certa forma amistosas de comércio desde os tempos coloniais. A maior parte dos conflitos podia ser identificada nas regiões fronteiriças, bastante móveis no período, conforme verificamos no mapa a seguir (BARNES, 2010, p. 75).

Anos 90, Porto Alegre, v. 22, n. 41, p. 173-208, jul. 2015 


\section{Distribuição das Nações Indígenas no começo do século XVI ${ }^{* * *}$}

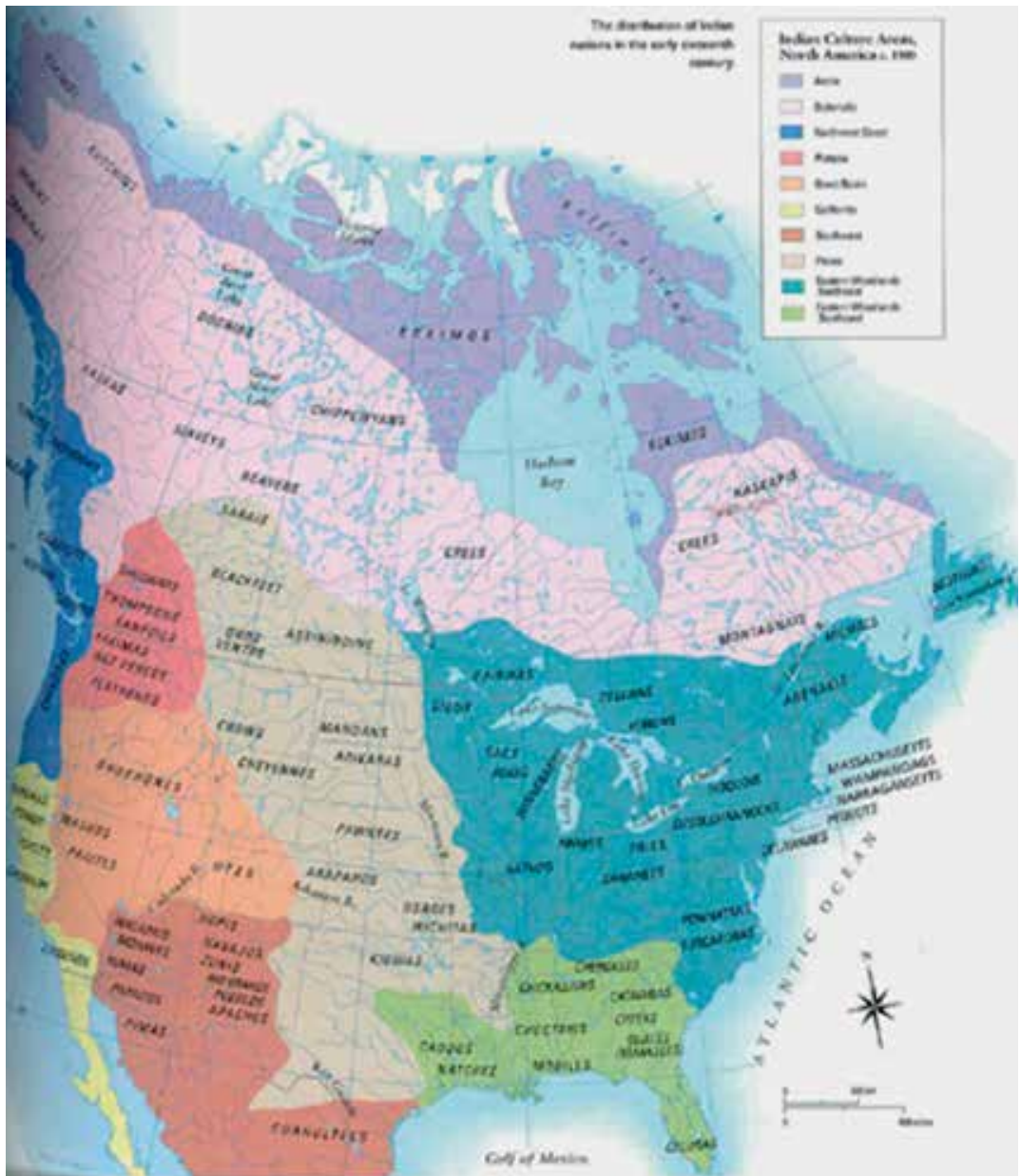

Fonte: BARNES, 2010, p. 75

Para as regiões ainda não exploradas por colonizadores, alguns tratados mantinham relações amistosas, como o Treaty of Fort Laramie *** As autoras deste artigo fazem uso de um mapa sobre o século XVI para inteirar, grosso modo, a disposição espacial da presença de diferentes grupos étnicos no atual território dos Estados Unidos, Canadá e parte do México.

Anos 90, Porto Alegre, v. 22, n. 41, p. 173-208, jul. 2015 
(1851), no qual os índios das planícies e do norte das Montanhas Rochosas permitiam a passagem de imigrantes, a construção de estradas e acampamentos militares (Idem, p. 291). Um primeiro grande boom de imigração para as regiões centrais esteve relacionado com "as corridas pelo ouro", iniciadas por volta de 1859 . As possibilidades de enriquecimento rápido e fácil atraíram milhares de colonos e de empresários das ferrovias, que rapidamente iniciaram a construção de transcontinentais. Mas, foi somente no decorrer e após a Guerra Civil (1861-1865) que podemos identificar o período dos maiores e mais sangrentos conflitos envolvendo índios, colonos e o exército norte-americano, conhecido oficialmente como Guerras Indígenas. Apesar de todos os grupos, em um momento ou outro, terem estado em conflito direto com os recém-chegados, Apaches e Sioux foram certamente os mais "celebrados" em sua resistência, fazendo com que alguns de seus líderes, como Red ClouD e Crazy Horse ficassem conhecidos e tivessem suas imagens coladas aos mais variados ícones culturais norte-americanos. Com o fim da Guerra Civil, o Estado iniciou uma política de confinamento dos grupos em reservas controladas principalmente pelo exército. Nelas, a sua segurança estaria garantida; o que, de fato, não ocorreu. Em todos os estados, houve batalhas militares longas para "acomodar" os grupos resistentes e submete-los às novas regras. Dois marcos desse momento ficaram conhecidos como símbolos da violência da conquista e, ao mesmo tempo, do fechamento do processo ${ }^{3}$. Um é o episódio conhecido como "o massacre de Sand Creek" (1864), no estado do Colorado, onde a milícia local, mesmo com ordens contrárias, assassinou brutalmente um grupo Cheyenne e Arapaho. O outro é "o massacre de Wounded Knee" (1890), em Dakota do Sul, onde, também de forma bárbara, padeceu um grupo Lakota.

Naquele momento, os primeiros discursos produzidos tentavam justificar o avanço sobre as terras indígenas através de sua representação como selvagens, entraves à civilização, receptores passivos da religião, seres condenados ao passado e à extinção (SHEPHERD, s/d, p. 02). Foi nesse contexto que Henry Louis Morgan, pai fundador da antropologia americana, a partir de seus estudos sobre os Iroquois, estruturou os parâmetros de análise de parentesco através da criação do método comparativo. Seu interesse por esse grupo específico, uma 
confederação de cinco nações, em verdade, provinha do fato de viver próximo a uma reserva em Rochester, estado de New York. Com o auxílio do filho de um chefe Seneca, seu tradutor, escreveu seu primeiro livro em 1851. Nesse texto, trazia suas considerações sobre o "destino manifesto dos índios" dentro da chave da impossibilidade de sua sobrevivência fora dos parâmetros civilizadores, motivo pelo qual sua rudeza deveria ser arrancada de forma branda, através da educação e da religião. Entre seus questionamentos e suas preocupações, apontava a dúvida sobre o compromisso do governo com a tutela das 'raças' indígenas para além das questões concernentes àquele tempo, mas com a "elevação final aos direitos e privilégios de cidadãos norte-americanos” (MORGAN, 1851). Publicado em 1871, período ápice da violência no Oeste, Systems of consanguinity and affinity of the buman Family, compilava os estudos comparativos de parentesco que ele havia empreendido em aproximadamente duas décadas envolvendo grupos dos EUA, Índia, Oceania, África e Oriente Médio. Os dados coletados nos EUA provinham através de questionários enviados para missões e agentes oficiais do interior. Posteriormente, produziu uma análise sobre a evolução da sociedade em que a dividia em estágios: selvageria, civilização e barbárie. Essa visão também estava refletida no conceito de fronteira de Frederick Jackson Turner, expoente simbólico e teórico da conquista do Oeste. Coincidentemente, ou não, Turner apresentou seu trabalho de doutoramento em História em 1890, ano do "fechamento do Oeste", com um estudo sobre o comércio de peles em Wisconsin: The Character and Influence of the Indian Trade in Wisconsin, anterior aos artigos em que as teses sobre fronteira apareceriam. Também pode ser considerado bastante expressivo da ligação entre o papel dos indígenas e a História do Oeste, a apresentação do artigo The significance of the frontier in American History, durante a Feira Mundial de Chicago, mesmo palco onde Buffalo Bill encenava seu espetáculo sobre a conquista do Oeste e a derrota dos índios. ${ }^{4}$

As produções que se seguiram fizeram crer que a história dos índios terminava em 1890, com as últimas batalhas militares contra os Apache, e a derrota simbólica dos Sioux no Massacre de Wounded Knee. Como resultado, antropólogos como Franz Boaz, James Mooney, and Alfred Kroeber assumiram o papel de catalogação dos grupos fadados ao desaparecimento para museus e universidades do país, 
Sobrevoando histórias: sobre índios e historiadores no Brasil...

originando um gênero que ficou conhecido como antropologia de resgate (SHEPHERD, s/d, p. 2), condizente com a fase assimilatória vivida na realidade. Somente com a publicação de And Still the Waters Run (1940), da historiadora Angie Debo, inaugurava-se um novo momento, em que as denúncias revelavam a pilhagem das terras indígenas por diversos setores, com ampla conivência do Estado, e a violência desses processos. Seu texto, audaciosamente, explicava a expansão para o Oeste calcada na exploração dos índios e de suas terras, e não baseada no destino manifesto. Entretanto, o estilo denúncia colocava os índios em um papel de vítimas passivas e ela mesma, nas margens acadêmicas, visto que nunca pôde firmar seu lugar em instituições de ensino superior. Na mesma linha de Angie Debo, os trabalhos de Alvin Josephy's (1965) e de Donald Berthrong's (1976)5 contribuíram para mostrar como a ação do Estado e da Igreja, em tentativas agressivas de incorporação, prejudicaram a autonomia das comunidades. Porém, não incluíram as vozes indígenas e suas interpretações não foram capazes de incorporar criticamente como os índios se adaptaram e incorporaram as mudanças que ocorriam ao seu redor, dando uma visão única de seus passados (SHEPHERD, s/d, p. 04).

Muito do que foi escrito posteriormente, enquadrava-se dentro dessa escola do "índio vitimizado", mas as perspectivas ampliavam-se através do intenso diálogo com os Movimentos dos Direitos Civis e de contestação à guerra do Vietnã. Como atesta Denise Bates (2012), é impressionante perceber como o papel dos ativistas indígenas nas discussões raciais e de discriminação, lutas por educação e melhorias materiais para grupos em situação crítica de pobreza dos anos 1950 e 1960 foi minimizada ora perante os movimentos raciais negros, ora pela invisibilidade dessas pessoas para a sociedade americana ${ }^{6}$. Também é preciso dizer que, embora vitimizados na historiografia, durante os anos 1960 e 1970, elementos culturais indígenas protagonizavam formas de protestar da contracultura: vestuário, penteados e costumes da cultura hippie eram inspirados na cultura indígena?.

Com os trabalhos de Vine Deloria, Custer Died for Your Sins: An Indian Manifesto (1969) e de Dee Brown, Bury My Heart at Wounded Knee (1971), a ideia de resistência somava-se à vitimizaçãa. No primeiro, observamos o resultado prático da crescente organização do movimento indígena e de seus intelectuais orgânicos no final dos anos 
1960 (Red Power). Escrito pelo ativista Sioux, além de tratar dos assuntos concernentes à história do grupo ao qual pertence, o livro abordava temas como discriminação racial e consequências da desapropriação em um tom de acusação contundente à cultura americana, aos antropólogos e ao cristianismo (SHEPHERD, s/d, p. 4-5). Já o best seller de Dee Brown, além de inserir-se na chave vitimização-resistência, acabou contribuindo para o reforço do mito do nobre selvagem.

Após a segunda guerra mundial, antropólogos também estavam engajados na produção de conhecimento sobre o passado indígena: ao combinarem os métodos de pesquisa antropológica e histórica, majoritariamente, a ida aos arquivos no caso da última, terminaram por criar uma metodologia híbrida conhecida como etno-história. Inaugurava-se um período de grande interesse pela perspectiva dos grupos nativos sobre os eventos (agency), sobre como as mudanças e as permanências processaram-se ao longo do tempo (AXTELL, 1979, p. 03). Dos usos desta renovação metodológica, na década de 1980, uma nova geração de estudiosos sobre a temática indígena emergiu. Influenciados pelos trabalhos da década de 1960, combinaram o método etno-histórico, advindos da teoria da história social, com estudos e teorias do simbolismo cultural de Clifford Geertz e Marshall Sahlins, no intuito de colocar os povos indígenas no centro da história como agentes ativos das mudanças. Surgia uma "Nova História Indígena”, denominação que congrega um corpo muito diverso de temas e objetivos.

Ao colocar a perspectiva dos próprios indígenas em foco, em análises cuja chave era a agência, e não um entendimento de suas ações como reações, esses estudos abriram espaço para questionar as narrativas tradicionais da história americana. Nas palavras de Shepherd, os " [...] índios tiveram um impacto sobre o curso do desenvolvimento americano, não como um obstáculo, mas como um formador ativo da história" (s./d., p. 7). São expoentes da "Nova História Indígena” James Merrill, James Axtell, Gregory E. Dowd, RD Edmunds, Richard White, Colin Calloway, Jean M. O’Brien, Daniel Richter e Theda Perdue 8 . A maior parte desses estudos trata do período colonial e do século XIX, contendo discussões sobre gênero, trabalho, meio ambiente e processos de urbanização. Numa espécie de reinterpretação das histórias coloniais mainstrem, mostram que, ao incluir as populações nativas, pode-se ter entendimentos completamente distintos do que até 
então se presumia. James Axtell (1985), por exemplo, enfatiza como as políticas indigenistas coloniais foram delineadas pelas ações indígenas, que orquestraram regras comerciais e de ocupação territorial sob as quais os não índios tiveram que se submeter para garantir o domínio das áreas e, muitas vezes, os indígenas puderam impedir, mesmo que temporariamente, os projetos expansionistas coloniais. Axtel demonstra, ainda, como os índios foram capazes de incluir elementos culturais europeus e manter, ao mesmo tempo, suas referências prévias. Essa ideia também é trabalhada por James Merrill em The Indians New World: The Catawbas and Their Neighbors from European Contact to Removal (1989), em que apresenta o conceito de "novo mundo" para europeus e índios. Em seguida, em New Worlds for All: Indians, Europeans, and the Remaking of Early America (1997), Collin Calloway também se debruça sobre essa problemática. Esses autores mostram como as doenças, o comércio, os colonos, os assentamentos, as coroas, o mercado, os recursos e a religião interagiram para criar um "novo mundo", que não era nem a Europa nem a América pré-contato.

Até aí, podemos verificar que a "Nova História Indígena" teria uma tendência a enfocar aspectos positivos do passado indígena, mesmo que suas análises não neguem os resultados práticos das conjunturas em questão, em que os grupos perderam sua autonomia e independência, ou foram aniquilados. Assim, ao abordar esses pontos, Richard White, em The Roots of Dependency: Subsistence, Environment, and Social Change Among the Choctaws, Pawnees, and Navajos (1983), apresenta uma nova perspectiva historiográfica aos estudos indígenas. Esse impactante trabalho abordou temas como a possibilidade de uma visão utilitarista do meio ambiente por parte dos índios em contraposição ao mito do "índio-ecologista" e também se debruçou sobre como esses grupos participaram do comércio colonial, tendo em vista os limites do controle que eles tinham sobre sua própria inserção. Já em seu trabalho mais conhecido, The Middle Ground: Indians, Empires, and Republics in the Great Lakes Region, 1650-1815 (1991), Richard White explora como europeus e índios forjaram um universo no qual as forças eram equiparadas, onde cada um podia ver ao "outro" como estrangeiro e criar, sobre esses parâmetros, um universo compreensível que se sustentou por duzentos anos, e como esse mesmo mundo se desfez após a era das Revoluções. O Middle Ground seria um lugar (as 
"bordas do império", nesse caso a região dos Grandes Lagos) onde a frouxidão das diretrizes coloca-se ora pela distância, ora pela falta de vontade dos personagens de colocar em prática as regras; e ao mesmo tempo um estado de espírito, no qual ajustes e incompreensões produziram um modelo novo para resolver situações complicadas, não havendo, segundo White, distinção entre história indígena e branca, nem prevalência demarcada de forças de uns sobre os outros.

Com a colaboração de outros autores, a "Nova História Indígena" deu conta de diversas regiões e períodos, como os primórdios da fase Nacional e o que ficou conhecido com "Indian Removal". Temas antigos foram sendo revisitados, como as políticas estatais e as suas implicações jurídicas, as intenções assimilacionistas e o respaldo científico que as embasavam. Questões como qual a responsabilidade do Estado pela perda da terra pelos indígenas, e quais efeitos as realocações trouxeram para as comunidades estiveram na pauta nos anos de 1980 e 1990. Foi também neste período que surgiram muitos estudos voltados para questões de gênero, educação e fronteira, além do formidável avanço no conhecimento da história do século XX mais recente, que solapa, de uma vez por todas, a ideia de desaparecimento ou assimilação total dos índios. Em vez disso, mostram o crescimento das comunidades e a continuidade de sua busca por direitos e reconhecimento. Também como parte desse cenário, temos a considerável produção histórica elaborada por estudiosos nativos?.

Para Ned Blackhawk (2005, p. 15), durante os anos 1990, no contexto de comemorações dos quinhentos anos da Conquista e as revisitações do passado, os estudos indígenas tiveram grande destaque, e afirma que "[...] se foram os dias em que os historiadores podiam casualmente descartar ou ignorar a poderosa e diversa constelação de populações nativas do continente". Segundo Blackhawk, os estudos mostraram como houve, em finais do século XIX e início do XX, um crescimento da capacidade do governo americano de aprovar, policiar e colocar em prática as políticas indigenistas. Outros historiadores aprofundaram o entendimento sobre as políticas assimilacionistas focadas em crianças, confinadas em internatos religiosos (2005, p. 15).

Segundo Pekka Hämäläinen (2012), os historiadores da, hoje velha, Nova História Indígena, buscavam colocar os indígenas no centro das coisas, na tentativa de reformular as narrativas oficiais, que 
haviam "trancado as populações nativas no lado errado da modernidade", tendo sido bastante bem sucedidos nessa empreitada. Estudos revolucionaram a história dos EUA durante o último quarto do século $\mathrm{XX}$, sendo o período colonial aquele em que o impacto desses estudos foi maior a ponto de os intelectuais utilizarem o termo "indigenous turn" (virada indígena). Entretanto, o autor coloca em consideração que, para alguns estudiosos, esse sucesso seria, justamente, o primeiro sinal do esgotamento "do momento criativo" do campo. A história indígena tornou-se mainstream, juntamente com estudos sobre fronteiras, história ambiental e do imperialismo; conta com um já sólido corpo de estudiosos e há perspectivas de estudos que aprofundem os conhecimentos sobre temas de grande interesse como gênero, escravidão, sexualidade e casamentos mistos, para dar alguns exemplos.

Durante as últimas décadas, as comunidades indígenas americanas foram capazes de reestruturar sua organização e alcançar avanços demográficos, econômicos e sociais. Esse fortalecimento, acompanhado de um aumento substancial na formação de intelectuais nativos, fez com que suas vozes pudessem alçar voos mais amplos, reivindicando espaço na construção de narrativas históricas e mesmo contestando a legitimidade de outras. O campo tornou-se um terreno de contestações, em que a produção do conhecimento e sua recepção tornaram-se tão importantes quanto o impacto que esses estudos produzem na vida prática das comunidades. Para Hämäläinen, esse diálogo já está gerando resultados através de estudos, produzidos por indígenas e não indígenas, que superam as lacunas entre as expectativas das comunidades indígenas e das práticas acadêmicas estabelecidas. Em suas palavras, "[...] os estudiosos agora escrevem diretamente sobre a dor e o trauma psicológico dos povos nativos, nos sensibilizando para as dimensões humanas do racismo e da expropriação e nos obrigando a chegar a um acordo sobre a violência generalizada da história americana". De fato, temas tabu têm sido postos em pauta, como a relação entre escravidão africana e indígena, limpeza étnica e genocídio cultural. Estas e outras linhas de trabalho têm realinhando a história indígena americana e podem modificar a forma como entendemos o multiculturalismo, a democracia, a soberania, bem como o papel do Estado-nação na sociedade americana moderna. Assim, a história indígena tornou-se um tema internacional e, há 
algum tempo, principalmente após os quinhentos anos da chegada de Colombo, os temas indígenas têm recebido atenção de intelectuais, ativistas e governos no mundo todo, alimentando a expectativa de que os diálogos sobre o tema serão cada vez mais comparativos e transcontinentais. A criação da Native American and Indigenous Studies Association, em 2008, é um grande símbolo disso.

Mesmo com visões bastante otimistas, ainda existe espaço para insatisfação dos estudiosos da temática, principalmente com a falta de reconhecimento e inclusão dos resultados das pesquisas nos programas das Universidades Americanas, sem falar nos currículos escolares. Em maio de 2013, a Newberry Library - um dos maiores centros de documentação sobre historia dos índios no mundo promoveu o evento $W$ by You Can't Teach U.S. History without American Indians (Por que você não pode ensinar a história dos Estados Unidos sem os índios). O encontro reuniu pesquisadores nativos e não índios de todas as regiões do país em diversos períodos de estudo. Sua queixa comum: a falta de interesse de outros pesquisadores em reconhecer a importância da inclusão da História dos Índios nas narrativas sobre a História Norte-americana ${ }^{10}$.

O cartaz do evento traz uma conhecida pintura de Benjamin West. Ela retrata uma cena de interação entre índios e europeus em 1683, quando William Penn negociou um acordo de paz com o chefe do grupo Lenape (Delaware) perto de uma aldeia na Pennsylvania (BARNES, 2010, p. 145). Concluída quase um século depois (17711772), a pintura foi inspirada em um retrato feito de memória por uma testemunha ocular do encontro. Num jogo de imagens feito pelos idealizadores do evento, os índios foram 'deletados' da obra, fazendo com que ela ficasse incompleta de tal modo que a história retratada perde o sentido. A constatação de que sem os índios não é possível explicar e entender o cenário é imediata. Por outro lado, sua deleção deixa marcas tão profundas na obra de arte original que, apenas com as suas sombras, é possível dar conta não só do significado da ausência dos índios na história, como também da presença de indícios que indicam que algo indispensável à sua compreensão foi dado como inexistente. Isso faz com que estudiosos pensem em estratégias sobre como lidar com situações em que, não apenas hipoteticamente, mas, de fato, os índios são tidos como desimportantes no processo histórico. 
Sobrevoando histórias: sobre índios e historiadores no Brasil...

Figura 1: Cartaz de divulgação do evento comemorativo dos quarenta anos do D'Arcy McNickle Center, realizado nos dias três e quatro de maio de 2013, na Newberry Library, em Chicago

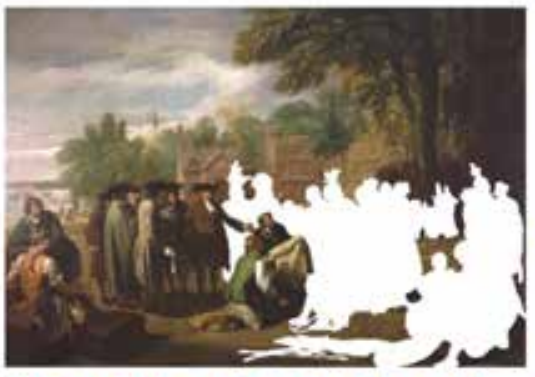

Why You Can't Teach U.S. History without American Indians

A Newberry Symposiam Commemorating the 40th year of the MeNickle Center

Spansond by the Office of the Dwun of Graduate Studilen at Michigan State University

\section{Fridlay, May 3 to 4, 2013}

Rugeles Hall, The Newberry, Chicazo

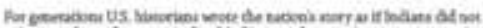

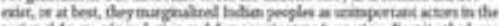

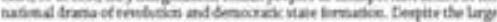

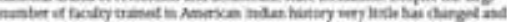

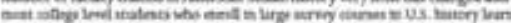

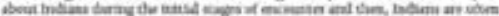

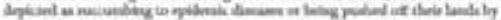

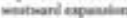

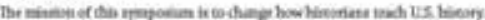

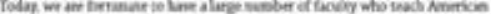

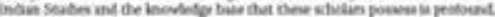

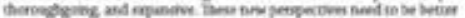

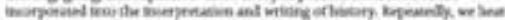

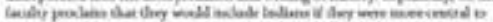

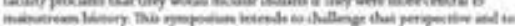

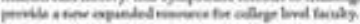

ww.newberry.org/why-yourcant-teach

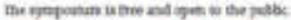

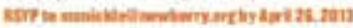

THE NEWBERRY

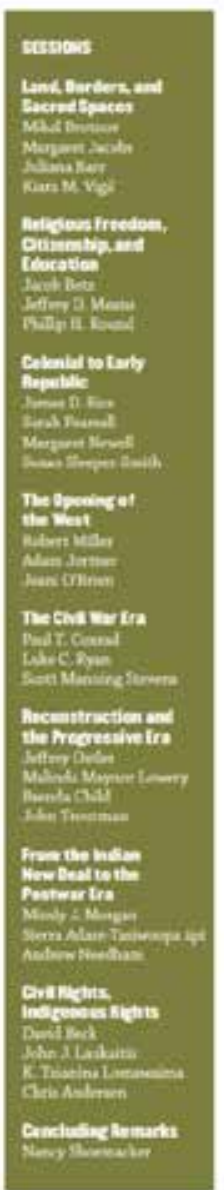

Fonte: Disponível em: http://www.newberry.org/search/site/why\%20you\%20 can $\% 26 \% 23039 \% 3 \mathrm{Bt} \% 20$ teach. Acesso em: 14 set. 2014.

Anos 90, Porto Alegre, v. 22, n. 41, p. 173-208, jul. 2015 


\section{Figura 2: O Tratado de Penn com os índios, óleo sobre tela. (1771-1772).}

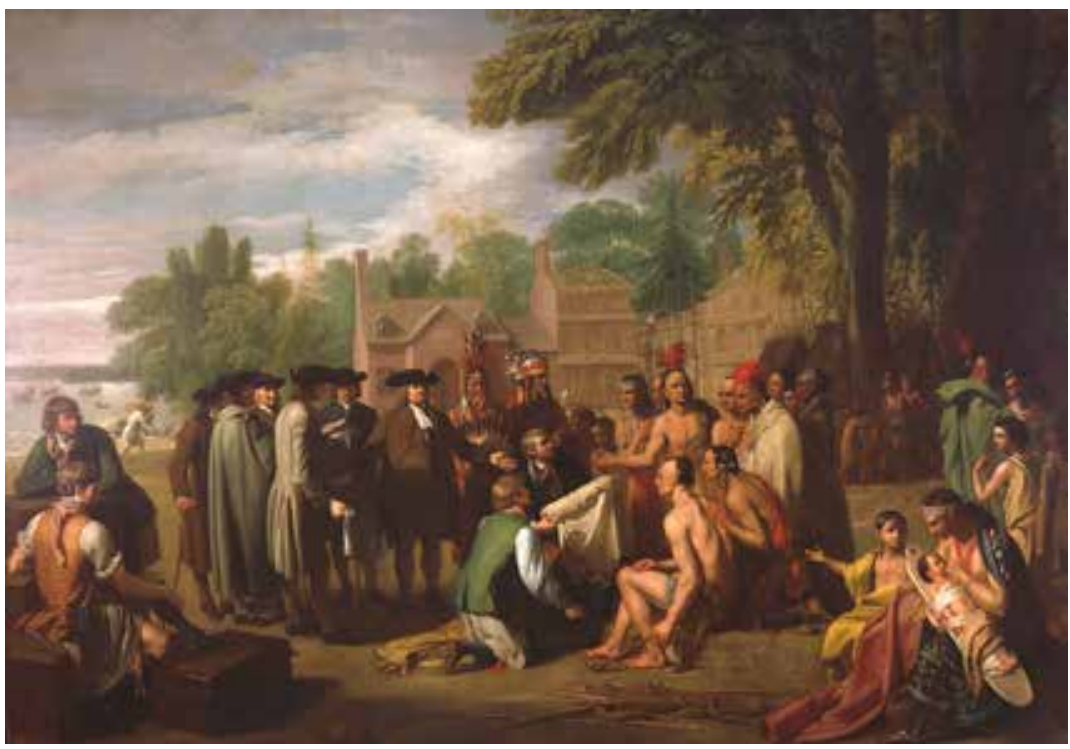

Fonte: Disponível em: http:/ / withart.visitphilly.com/artworks/penns-treaty-with-the-indians/. Acesso em: 21 jul. 2015.

\section{Sobrevoando as Terras Baixas}

Foi no século XIX que floresceu a historiografia brasileira. A questão indígena confundiu-se com as práticas e a produção dos discursos. Em 1839, ao inaugurar o Instituto Histórico e Geográfico do Brasil (IHGB) ${ }^{11}$, o Estado assumia o papel de "criador" de uma história nacional e oficial. Seu primeiro grande e simbólico ato foi o lançamento do Concurso Como Escrever a História do Brasil. O vencedor foi o botânico e etnógrafo Carl Friedrich Philippe von Martius, que havia feito pesquisas sobre língua e cultura indígenas em parte do Brasil e afirmava que os índios estavam fadados ao desaparecimento. Na história do Brasil de von Martius, os índios foram apresentados de forma romântica, quase confundidos à natureza, felizmente acolhidos pelo colonizador português em sua inteligência civilizadora. 
Coube a ele mostrar como a influência moral do branco sobre os índios engrandeceu a nação, e em menos de cinquenta páginas ele expos ideias como a de que "[...] o sangue português, em um poderoso rio, deverá absorver os pequenos confluentes das raças índia e etiópica" (MARTIUS, [1854] 1982, p. 88).

O projeto premiado de escrita da história de von Martius, fundado na presença das três raças na constituição do Brasil não vingou. Entre 1854 e 1857, Francisco Adolpho de Varnhagen publicou, em cinco volumes, a obra História geral do Brasil, sob o patrocínio imperial. No primeiro volume, de 1854, ele assentiu: para os índios, "[...] povos na infância, não há história: há só etnografia" (VARNHAGEN, 1962 [1854], v. 1, p. 42). Tratava-se de uma noção que excluía os índios da historiografia, os detratava quando os mencionava e indicava sua escravidão e seu extermínio físico. $\mathrm{O}$ projeto com relação à história dos índios foi fruto de uma cultura de época e serviu a interesses muito distintos. Além disso, não foi uma unanimidade e entrou em confronto com visões mais amenas. Obras como as de João Francisco Lisboa, Capistrano de Abreu, Couto de Magalhães, Gonçalves de Magalhães e Gonçalves Dias produziram trabalhos etnográficos e de defesa do "salvamento" daquelas populações ou resultaram em comemoradas produções literárias sobre os índios. Gonçalves de Magalhães, por exemplo, é autor de $A$ Confederação dos Tamoyos (1857), uma epopeia que toma o sacrifício e o heroísmo indígena como marco fundador da nação brasileira através da morte de Aimberê, o último sobrevivente da nação tamoia, massacrada pelo colonizador português. Inspirada na obra literária, a pintura $O$ último tamoio, de Rodolfo Amoêdo (1857-1941), foi exibida na Exposição Geral de Belas Artes no Rio de Janeiro, em 1884 (SCRICH, 2009).

Embora visões e projetos sobre os índios fossem diferentes no Oitocentos, partilhavam os mesmos pressupostos de excluí-los da historia. Desde o final do período colonial, a monarquia portuguesa precisou realizar uma série de ajustes políticos no que dizia respeito aos indígenas, visto que havia não apenas diferentes projetos teóricos, mas distintas práticas espalhadas pelas províncias, segundo as histórias das relações de ocupação territorial, mestiçagem e utilização da mão de obra. Foram amplas as frentes de discussões 
sobre o que fazer com os índios do presente: se formariam o corpo de trabalhadores tão caros à nação; se seriam entregues às missões religiosas e devidamente trazidos ao seio da civilização (aqui também por meio do trabalho); ou ainda, se serviriam ao papel de guardas das fronteiras, conforme projeto do Gen. Couto de Magalhães, através das colônias militares; e, claro, as propostas de extermínio. Em São Paulo, por exemplo, ainda imperava a perseguição de índios e sua escravização, de acordo com a Carta régia de 1808, e mesmo com a lei de proibição, em 1831, à revelia do Direito, muitos índios encontravam-se nessa condição. Em outras situações, como no Rio de Janeiro e em Pernambuco, eram grandes as disputas entre ex-colonos e índios sobre as terras de aldeamentos formados em tempos coloniais.

Em 24 de julho de 1845, foi aprovado o Decreto 426, conhecido como "Regulamento acerca das Missões de Catequese e Civilização dos Índios" ou, simplesmente, Regulamento das Missões, tornando-se a Lei Indígena do Império. Atribuía aos Diretores Gerais a função de administrar antigos aldeamentos e criar novos para atrair os indígenas hostis dos sertões. Aos padres, capuchinhos em sua maioria, cabia a missão civilizadora perante o indígena, em que ele seria instruído e assimilado à nação. Juridicamente incapaz, a cidadania era negada como lhe fora também a participação na História pelos pais fundadores. Com a Lei de Terras de 1850, os territórios indígenas passavam a ser de propriedade do Estado, bem como a definição de terras ocupadas ou devolutas, e seus direitos atrelavam-se à condição de "assentados". Estava posto o cenário histórico das maiores expropriações territoriais e confrontos entre a nação, os índios e imigrantes estrangeiros ${ }^{12}$. É este o caso da Companhia de Comércio e Navegação do Vale do Mucuri, fundada no interior de Minas Gerais entre 1850 e 1860, por Teófilo Ottoni. Deputado por aquela província, Ottoni incentivou o desenvolvimento e a colonização na região onde, segundo ele, "construirei minha Philadelphia". Ele escreveu pelo menos cinco livros e dois relatórios sobre a Companhia, a importância de seus privilégios, o escopo de seu projeto e a relação com os 'selvagens' ${ }^{13}$. Depois da Lei de Terras de 1850, o governo passou a exercer mais controle sobre as companhias de colonização. Mesmo assim, os planos de Teófilo Ottoni foram executados sem barreiras opressivas. 
Essa constância quanto ao "problema indígena”, parecia conciliar violência e filantropia, ambos pertinentes ao projeto de civilização, encontrando representantes nos sertões e nos gabinetes (MONTEIRO, 2001, p. 147-157). Todos esses dilemas encontram-se nos artigos da Revista Trimestral do IHGB, nas pesquisas sistemáticas sobre as raças indígenas realizadas pelo Museu Nacional a partir dos anos 1870 e, claro, na realização, em 1882, da Exposição Antropológica, no Rio de Janeiro. Ali, as novas e internacionais discussões sobre raças e evolução encontraram eco profundo em um já bastante complexo debate sobre o significado dos índios do passado e do presente: como se acomodaria essa classe de homens de valores tão indefinidos na construção da nação? Através de estudos linguísticos, craniométricos, etnográficos ia-se cumprindo o desinteresse pela participação histórica nos mais diversos processos.

Ao contrário do que muitos pensam, foi durante os séculos XIX e início do XX, e não no tempo colonial, que se deu a expansão e ocupação da maior parte do Brasil interior. Durante a década de 1840, iniciou-se um trabalho de demarcação das fronteiras através do uso de documentação espalhada pelas províncias com a participação dos membros do IHGB, fronteiras essas, que tiveram sua fragilidade evidenciada durante a Guerra do Paraguai. Mas, em 1891, um dos estados mais ricos da nação, São Paulo, ainda apresentava nos mapas, sob um terço do seu território, a expressão Terrenos desconbecidos, para desgosto das autoridades (CAVENAGHI, 2004, p. 193). O mesmo tipo de decepção pode ser percebida quando ocorreu a revolta dos indígenas do aldeamento do Itambacuri (MG), em 1893, “"...] colocando em questão a eficácia da política de aldeamentos, estabelecida com tanta expectativa na legislação de 1845 e combatida com tanto furor ao longo do Segundo Reinado pelos descrentes que achavam que a civilização dos índios se resolvia com bala e pólvora" (MONTEIRO, 2001, p. 165). Nos sertões desconhecidos de todo o país, ocorriam enfrentamentos entre as populações das frentes de expansão e os grupos indígenas. Nacionais e imigrantes, pequenos e grandes proprietários - o caso das lavouras de café em São Paulo e no Paraná, e da extração da borracha no Norte são emblemáticos -, e o advento de empreendimentos públicos e privados, como a construção de estradas de ferro e a instalação de linhas telegráficas, motivaram chacinas e perseguições de fins verdadeiramente trágicos para os índios.

Anos 90, Porto Alegre, v. 22, n. 41, p. 173-208, jul. 2015 
Dentro desse contexto de instabilidade total, as alternativas para o "problema indígena" novamente se colocavam. Uma delas seria a busca de um tratamento mais humanitário desses grupos, surgida no seio do exército - principalmente daqueles que participavam da exploração dos sertões através da instalação de telégrafos. Essa linha, também podia ser observada nas propostas do Apostolado Positivista, que via no indígena, um ser na fase inferior do progresso humano, mas que poderia alcançar a civilização com o auxílio dos que já a viviam. O expoente intelectual e sintetizador das novas ideias era Cândido Mariano Rondon, que se tornou figura cativa da mídia na virada do século, apresentando resultados práticos da viabilidade de tratar o índio sem violência. A outra possibilidade ainda era a do extermínio: em 1908, a publicação do artigo de Herman Von Hering na Revista do Museu Paulista evidenciava mais uma vez que a vida e o futuro dos índios eram incertos. O certo é que, naquele momento, houve uma crescente pressão para a criação de um órgão de proteção e civilização dos índios. Alguns aspectos gerais constituíam a demanda em que claramente prevaleceu a influência positivista: a demarcação das terras indígenas; a proteção e a garantia de suas vidas; a punição dos crimes contra eles praticados; a laicização da civilização. O Estado republicano finalmente assumiu a responsabilidade sobre o destino dos índios ao criar, em 1910, o Serviço de Proteção aos Índios e Localização de Trabalhadores Nacionais (SPILTN). Conforme Gagliardi, praticamente sem recursos e vivendo sob constantes ameaças de fechamento, logrou não colocar em prática a maioria dos seus intuitos. $O$ órgão contribuiu para o confinamento dos grupos em territórios pequenos e impróprios, que continuaram sendo disputados com outros segmentos. Foram vítimas de trabalhos forçados, doenças, prostituição e estigmas sociais como a sua incapacidade para o trabalho.

Nos meios intelectuais, por um lado, permanecia uma vontade geral de entender e firmar o que seria a identidade nacional; por outro, um esforço em conhecer melhor sociedades indígenas tidas como em vias de extinção. Isso pode ser exemplificado através da Semana da Arte Moderna de 1922 e através da trajetória profissional de Curt Unckel Nimuendajú e sua rede de relações. Na Semana da Arte Moderna, que aconteceu em São Paulo, a grande questão foi Tupi or not Tupi?

Anos 90, Porto Alegre, v. 22, n. 41, p. 173-208, jul. 2015 
Conectado a ela, esteve O Manifesto Antropofágico, apresentado por Oswald de Andrade em 1928. Nele, o escritor exalta a identidade e a criatividade brasileiras através das manifestações culturais. O documento é considerado um marco do Modernismo no Brasil e "Tupi, or not tupi that is the question" é uma das metáforas do manifesto, segundo o qual “[...] sem nós a Europa não teria sequer a sua pobre declaração dos direitos do homem" ". Também em 1928, Tarsila do Amaral retratou a brasilidade em Abopuru, a pintura símbolo do Modernismo nas terras baixas. A figura com pés gigantes fincados na terra e a cabeça minúscula que alcança a altura do sol parecem valorizar o trabalho braçal e sugere a ideia de homem selvagem, nativo, plantado em chão brasileiro, antropófago, que se alimenta ritualmente da carne do outro para adquirir sua força, como indica o próprio nome Abopuru, em tupi-guarani, o homem que come carne humana. Etnólogo alemão, Curt Unckel Nimuendajú dedicou-se à militância indigenista e à pesquisa etnológica ao longo das quatro primeiras décadas do século XX. Sua obra produziu valiosos registros etnográficos tanto sobre os grupos tupi-guarani, um dos quais o batizou com o nome indígena ${ }^{15}$, quanto sobre os grupos Jê. Nimuendajú manteve diálogo com o americanismo que nascia nos museus de etnologia na Europa e nos EUA, ao mesmo tempo em que fazia um árduo trabalho de campo coletando e catalogando objetos e artefatos da cultura material dos índios, dados sobre sua língua e relações de parentesco. Assumiu em seus escritos um tom trágico em relação ao futuro das populações indígenas. Mesmo assim, “"[...] seu empenho em etnografar a complexa organização social dos grupos Jê contribuiu, por sua vez, para que a moderna reflexão etnológica de David Maybury-Lewis e Claude Lévi-Strauss pudessem avançar sobre bases seguras nas décadas de 1950 e 1960 "16.

Já nas décadas de 1930 e 1940, verificamos continuidades e certa renovação na forma de tratar a participação dos índios na História. No primeiro caso, foi exemplar a postura de Caio Prado Jr., que, em Evolução Política do Brasil (1933), e em Formação do Brasil Contemporâneo (1942), relegava aos índios uma visão de vítimas dos processos de disputas territoriais e de mão de obra e, por vezes, apresentava preconceitos explícitos sobre eles: 
A população indígena, em contato com os brancos, vai sendo progressivamente eliminada e repetindo mais uma vez um fato que sempre ocorreu em todos os lugares e em todos os tempos em que se verificou a presença, uma ao lado da outra, de raças de níveis culturais muito apartadas: a inferior e dominada desaparece. E não fosse o cruzamento, praticado em larga escala entre nós e que permitiu a perpetuação do sangue indígena, este estaria fortemente condenado à extinção total (Apud Freitas).

Em 1933, também era publicado Casa Grande \& Senzala, de Gilberto Freyre, que novamente analisava a formação do Brasil a partir da fusão das três raças, positivando esse aspecto. Um dado interessante para este artigo, diz respeito à grande influência de Franz Boas nos trabalhos de Freyre, visto que foi nos EUA que obteve sua formação superior.

O segundo caso é representado pelo historiador Sérgio Buarque de Holanda. Em seus estudos sobre expansão e ocupação territoriais, ele adotou uma abordagem que incluiu os índios na história e mostrou ser central o seu papel na formação e concretização do projeto colonial luso. Em Raízes do Brasil (1936), Monções (1945), Caminhos e Fronteiras (1957), Visão do Paraíso (1959) e no inacabado O Extremo Oeste (1986), o autor parece ter incluído em um crescente os grupos indígenas nas análises: trata de redes de comércio, da mestiçagem, da utilização de caminhos e modos indígenas na relação com o meio, de sua participação na exploração dos sertões e em bandeiras. O autor também participou da elaboração da História Geral da Civilização Brasileira durante os anos 1960 e 1970, e com a colaboração de outros professores da Universidade de São Paulo (USP) - antropólogos e sociólogos como Egon Schaden e Florestan Fernandes - que apresentavam os índios, mas de forma pouco relevante, não correspondendo aos resultados da obra do próprio Sérgio Buarque. Ainda em aberto está o questionamento sobre por que, mesmo os índios ocupando um papel central nos estudos de um dos historiadores mais importantes do Brasil, esse fato não foi capaz de colocar os indígenas em evidência. 
Sobrevoando histórias: sobre índios e historiadores no Brasil...

O trabalho mais significativo sobre os índios no Brasil nos anos de 1950, foi escrito e publicado nos EUA, The Origin and Establishment of Brazil's Indian Service, 1889 - 1910, de David Hall Stauffer. Com valioso trabalho documental e narrativo, analisa o processo de expansão para interior no século XIX, além dos intensos debates sobre extermínio dos índios e a criação do SPI, valorizando amplamente a atuação de Rondon. No Brasil, sua publicação se deu de forma incompleta, tendo alguns capítulos traduzidos pela Revista de História da USP nos anos de 1960.

Durante a década de 1970 e boa parte dos anos 1980, os estudos históricos sobre os índios equivaliam a "crônicas de sua extinção", fruto de uma real situação de diminuição das populações. Exemplo deste tipo de abordagem é o importantíssimo estudo de Silvio Coelho dos Santos, Índios e brancos no sul do Brasil: a dramática experiência dos Xokleng (1973), no qual o autor, em um tom de denúncia, relata a história de confrontos entre colonizadores europeus, predominantemente de origem germânica, e os índios da etnia Xokleng, no estado de Santa Catarina. Àquela altura, o Brasil dos estados do sul e sudeste já vivia a negação da existência dos índios, vinculando-os com a floresta Amazônica ou ao recém-inaugurado Parque Nacional do Xingu ${ }^{17}$. Nos mesmos moldes, entretanto com uma análise menos refinada, por apresentar valiosíssimas fontes históricas, porém sem discuti-las, Ítala Irene Basile Becker apresenta uma história do grupo Kaingang no Rio Grande do Sul (1976) ${ }^{18}$. Outras produções nesse modelo são Red Gold (1978), de John Hemming, que fez um estudo sobre a América Portuguesa, e Carlos Moreira Neto, em Índios da Amazônia: de maioria a minoria (1988). Ambos tratam da exploração e destruição dos índios pelos processos de dominação colonial, resultando em abordagens cristalizadoras, que negativam as mudanças vividas - como integração ou assimilação - em termos de aculturação, diminuindo o "grau de indianidade".

Mas foi durante a década de 1990 que o Brasil também viu nascer a sua "Nova História Indígena". Fruto de um esforço coletivo para colocar os índios no centro dos processos estudados, procurou entender a sua "agência" como sujeitos, não como vítimas passivas e engessadas. O momento de renascimento dos movimentos sociais perante a ditadura militar - que havia sido denunciada internacionalmente 
sobre os atos cometidos contra populações indígenas - resultou na desmontagem do SPI e na criação da Fundação Nacional de Proteção ao Índio (FUNAI), em 1967. Essa virada acompanhou a emergência do movimento indígena em todas as partes do país, envolvendo militantes "orgânicos" e intelectuais, principalmente, nas áreas de antropologia e história. Com ampla participação na Assembleia Constituinte e aprovação do compromisso com as demarcações de terras assumidas pela Constituição Cidadã, tomou fôlego a produção de laudos e dossiês baseados em documentação - sobretudo do período colonial -, dada a reconfiguração dos direitos indígenas como bistóricos (MONTEIRO, 2001, p. 05). Nas universidades, novas orientações teóricas ampliaram as possibilidades de estudos sobre os índios dentro da antropologia, como visões mais dinâmicas de cultura, o uso de fontes orais, as possibilidades analíticas da etno-história.

A publicação de As Muralhas dos Sertões: os povos indígenas no rio Branco e a coloniz̧ação (1991), de Nádia Farage, simboliza a renovação no fazer histórico: sua análise documental dotada de sensibilidade etnográfica apresenta como os índios da região de Rio Branco, disputada por portugueses e holandeses, atuaram segundo intenções próprias na construção do universo colonial. Outros estudos publicados na década de 1990 corroboraram com a colocação dos índios no cenário historiográfico e são exemplos importantes: $A$ heresia dos Índios (1995), de Ronaldo Vaifas, tratou de um processo da Inquisição sobre um movimento profético sincrético (cristão e tupi) do interior baiano baseado na perspectiva da história cultural; Ronald Raminelli, em Imagens da Colonização. Representação do Índio de Caminha a Vieira (1996), debruçou-se sobre a temática da representação indígena com uso de fontes iconográficas e apontou um "descompasso" entre imagens e os relatos coloniais.

A publicação de História dos Índios no Brasil (1992), organizado pela antropóloga Manuela Carneiro da Cunha foi, sem dúvida, um marco importante. $\mathrm{O}$ trabalho reuniu resultados de pesquisa em história, arqueologia e linguística vinculados ao Núcleo de História Indígena e do Indigenismo da USP. Embora o livro seja uma contribuição importante para preencher vazios sobre a historia dos índios no Brasil, a própria organizadora reconhece que se trata de um conjunto fragmentado de estudos de casos, "[...] que permitem imaginar, mas

Anos 90, Porto Alegre, v. 22, n. 41, p. 173-208, jul. 2015 
Sobrevoando histórias: sobre índios e historiadores no Brasil...

não preencher as lacunas de um quadro [...]" que poderia ser mais completo. Em que se pese o pouco conhecimento sobre o assunto, o fato é que "[...] hoje está mais claro, pelo menos, a extensão do que não se sabe” (CUNHA, 2006, p. 11).

Em 1994, outro grande esforço para o estímulo de trabalhos em história indígena foi publicado: o Guia de Fontes para a História Indigena e do Indigenismo em arquivos brasileiros. Acervos das Capitais. Organizado por John Manuel Monteiro ${ }^{19}$, o instrumento de pesquisa agrega informações documentais e propõe um intercâmbio de informações sobre os índios. No projeto, uniram-se pesquisadores ligados a universidades em cada estado (apenas Tocantins, Amapá e Roraima não puderam ser contemplados). Assim como História dos Índios no Brasil, o Guia era uma tentativa de elaborar uma agenda engajada com o passado e com o futuro dos povos indígenas, rechaçando a tese do desaparecimento e unindo esforços em conjunto com as demandas dos próprios índios. Nas palavras do organizador, tratava-se de "um passo inicial - tímido, no caso de alguns estados, forte e decidido, em outros" (1994, p. 07), mas que impossibilitaria, daquele momento em diante, a explicação da ausência de história por carência de documentação.

É bastante significativa a publicação, no mesmo ano do Guia, do principal livro sobre história indígena no Brasil: Negros da Terra: indios e bandeirantes nas origens de São Paulo, de John Manuel Monteiro. O trabalho assumia, na prática, os compromissos e desafios da agenda anunciada anteriormente. Originado da tese defendida pelo autor em 1985, na Universidade de Chicago, o livro foi enriquecido por seus estudos nos anos seguintes. Negros da Terra consiste em uma interpretação renovada e crítica da história social do período colonial em São Paulo. O estudo mostra como praticamente a totalidade de aspectos da "[...] formação da sociedade e economia paulista durante seus primeiros dois séculos confundem-se de modo essencial com os processos de integração, exploração e destruição de populações indígenas trazidas de outras regiões" (MONTEIRO, 1994, p. 09). O livro aborda aspectos caros à historiografia brasileira, como a relação do trabalho dos índios com a economia colonial. Ainda maculada por uma espécie de mito, um equívoco largamente reproduzido em livros escolares, de que o índio não era apto para o trabalho, a 
historiografia carecia de um estudo exaustivo, com uso de fontes diversificadas, sobre escravidão indígena. Estampada no título do livro, está também a problemática sobre a relação entre a história dos índios e a história dos negros no Brasil. Negros da terra era uma designação usada para os índios, remetendo à equivalência e ao mesmo tempo a uma diferenciação entre eles e os negros da Guiné. Esses termos reportavam-se simultaneamente a uma equivalência de status servil e a uma diferenciação de origem (LANGFUR, 2005).

Outro estudo importante é a tese de livre docência do mesmo autor, do ano de 2001, intitulada Tupis, Tapuias e Historiadores: estudos de história indígena e do indigenismo. Nela, John Monteiro apresenta um conjunto elaborado de artigos e ensaios que tratam de temas e problemas seminais da historiografia indígena brasileira, muitos deles colocados nas discussões apresentadas anteriormente. Entre os temas centrais do conjunto estão a "defasagem e os deslizamentos temporais" quanto ao uso das fontes históricas; as refratadas construções etnográficas dos passados indígenas feitas em tempos imperiais; o estabelecimento de um "padrão bipolar" de análise do passado indígena, o padrão Tupi/Tapuia, muitas vezes travestido em outros nomes e colocado em distintos tempos históricos e historiográficos, ora analiticamente, ora como política para e pelos índios (2001, p. 08). Em análises astutas, o historiador tece ligações e desconstrói mitos sobre os períodos colonial e imperial brasileiro. O tema do extermínio historiográfico e real dos índios também perpassa todo o trabalho, mas ganha destaque no capítulo Entre o etnocídio e a etnogênese, em que o autor chama a atenção dos historiadores para a complexidade de formação de novas identidades surgidas no período colonial. Tais transformações podem ser vistas como estratégias políticas dos grupos ou indivíduos - o autor destaca a atuação das lideranças indígenas na chave da agência - "perante a catástrofe demográfica, as estratégias militares, evangelizadoras e econômicas dos europeus" (2001, p. 75). Assim, ao localizar o problema do vazio historiográfico sobre os indígenas no século XIX como fruto da relação entre suas próprias histórias e o surgimento da História como disciplina, John Monteiro esclarece problemáticas e contextos, bem como oferece pistas para o futuro da historia dos índios no Brasil.

Anos 90, Porto Alegre, v. 22, n. 41, p. 173-208, jul. 2015 
A produção de John Monteiro influenciou as gerações seguintes de historiadores dos índios. Sob sua orientação direta ${ }^{20}$ e em outros centros de pesquisa, diversos estudos avançaram em apontar a participação indígena na história e cobriram distintas temáticas e períodos. ${ }^{21}$ Essa primeira leva de pesquisadores, através de extensas pesquisas documentais, debruçaram-se especialmente sobre o período colonial. Temas como os conflitos gerados pela interiorização da conquista, a dependência dos colonizadores perante os índios e a consequente gama de alianças geradas e as disputas pela força de trabalho foram os principais pontos debatidos por Pedro Puntoni (2002) e Glóri Kok (2004). Outro problema trazido à tona pelos estudiosos dos índios nesse momento foi a relação entre a religiosidade e a vida em missões, evidenciando a complexidade do tema da tradução cultural, autores como Cristina Pompa (2003) e Almir Diniz de Carvalho Jr. (2005) são exemplos disso. A utilização de documentação produzida pelos índios foi explorada por Eduardo dos Santos Neumann (2005), demonstrando como os Guaranis se apropriaram com propriedade das instituições coloniais. Já a tese de Mariana de Campos Françozo (2009), apresenta como foram construídos, concomitantemente, os saberes coloniais por meio de análise da circulação de pessoas, objetos e discursos entre o Brasil e a Holanda.

A Maria Regina Celestino de Almeida cabe menção especial, visto que seu trabalho teve um importante alcance e colaborou para a divulgação da temática. Além disso, ela é responsável por toda uma outra leva de orientações na Universidade Federal Fluminense, um dos principais centros de produção do conhecimento histórico do país. Em Metamorfoses Indígenas: identidade e cultura nas aldeias coloniais do Rio de Janeiro (2003), a autora trata do lugar dos índios nas aldeias cariocas e as disputas pelo uso de seu trabalho e terras, bem como sua autoria quanto às decisões sobre esses processos. Esse trabalho modifica a visão estática e passiva sobre os índios ao oferecer uma nova leitura dos seus papéis de liderança, mediadores, aliados e por vezes inimigos dos portugueses na construção do universo colonial. Ao fazer uso de fontes variadas e provenientes de diversos lugares, algumas das quais bastante conhecidas, a autora mostra como interessantes processos de reconstrução das identidades e 
cultura indigenas foram forjados em espaços, onde, à primeira vista, não existiriam brechas para romper com a rígida hierarquia social dos tempos coloniais.

Para o período imperial e republicano, os trabalhos tornam-se um tanto mais escassos se comparados ao colonial. Mas alguns mostram a riqueza da gama de possibilidades, seja sob o aspecto das fontes, metodologia ou recortes: a discussão sobre o tema dos distintos regimes de historicidade proposto por Izabel Missagia de Mattos (2004) no contexto dos aldeamos capuchinhos; os problemas da imigração do século XIX e as possibilidades que levam em conta trajetórias de indivíduos nos contextos de contato através da adoção ou do rapto de indígenas são apresentados por Luisa Wittmann (2007). Lucybeth Camargo de Arruda (2012) mostra como o uso de fotografias pode ser uma interessante fonte para compreender a atuação indígena nos Postos do SPI, para além de uma visão que os colocava como receptáculos de políticas governamentais durante a década de 1940. Outros estudos têm se dedicado à compreensão do papel das lideranças indígenas nas lutas pelo direito territorial, como a tese de Edson Hely Silva (2008), que demonstra a força do uso de fontes orais para construção de novas narrativas históricas. $\mathrm{O}$ uso e a discussão sobre a memória indígena foi tratada por Giovani José da Silva (2009), na fronteira Brasil-Bolívia, sob uma atenta ótica transnacional dos processos vividos entre as décadas de 1930 e 1980. Também tem crescido o número de trabalhos sobre o Movimento indígena brasileiro, que em breve deverá contar com a produção de intelectuais "orgânicos".

Em toda essa reconfiguração ocorrida nas últimas décadas no campo da historiografia brasileira sobre os índios, os trabalhos e a atuação profissional de John Monteiro tiveram papel decisivo. Como vimos anteriormente, o pesquisador teve sua formação vinculada às transformações que o campo sofria nos EUA, e incorporou as inovações teóricas e metodológicas, principalmente oriundas da etno-história. Seu trabalho é fruto de um profundo conhecimento e diálogo entre a historiografia norte-americana e brasileira sobre os índios em ambos os países, tema central deste artigo. Atento às imagens dos índios na historia e na historiografia, o pesquisador fazia uso constante da analise delas nas aulas, cursos, palestras e 
conferências que ministrava. Em mais de uma ocasião, usou a imagem intitulada "Dança Tapuia", de Albert Eckhout. O pintor holandês acompanhou a corte de Mauricio de Nassal quando houve a ocupação holandesa de parte do atual nordeste brasileiro. Como funcionário da Companhia das Indias Ocidentais, desembarcou no Recife, em 1637 (BRIENEN, 2006). As pinturas de Eckout trazem consigo um conjunto importante de informações sobre o contexto da cultura visual da época, sobre os imaginários classificatórios dos holandeses e as maneiras escolhidas para retratar os índios, sobretudo os índios Tapuia, relativamente marginais do conjunto de representações coloniais voltadas para os grupos Tupi. A análise das imagens possibilita um melhor entendimento sobre tipos de as experiencias, materiais, ideias e práticas utilizadas pelos europeus para retratar o novo mundo. Além disso, oferece caminhos para repensar as dinâmicas coloniais à medida que recompõe relevantes relações entre a interferência editorial e a utilização política dessas imagens. Porém, para alcançar todo um conjunto de informações e questões que uma fonte histórica pode trazer, é preciso saber ler além das palavras, advertiu o historiador durante o I Fórum Internacional da Temática indígena, realizado em junho de 2010, em Porto Alegre. ${ }^{22}$ Atento às temporalidades, ao momento da produção da obra, ao momento de sua publicação e aos usos feitos da imagem, John Monteiro chamava a atenção para o fato de que a Dança Tapuia aparecia em sites e em capa de livro de maneira incompleta, com parte dos personagens ausentes da obra. Tal operação de apagamento era feita através de um recorte, que por sua vez descontextualizava e tornava impossível perceber a totalidade da história retratada. Assim, parte da compreensão da fonte feita literalmente pelas metades, John Monteiro enfatizava que, com os recortes, o historiador perde informações importantes sobre zoologia, botânica, técnicas de arte e contextos socioculturais, além da "devolução do olhar" de uma das personagens. Em outras palavras, perde a interação entre a fonte e o espectador proposta pelo autor da obra; interação essa tão fundamental para captar elementos da cultura de contato quanto aspectos sobre as ações dos índios. 
Figura 3: Dança Tapuia, óleo sobre tela, ca. 1643. Albert Eckout (ca. 1607- ca. 1666)

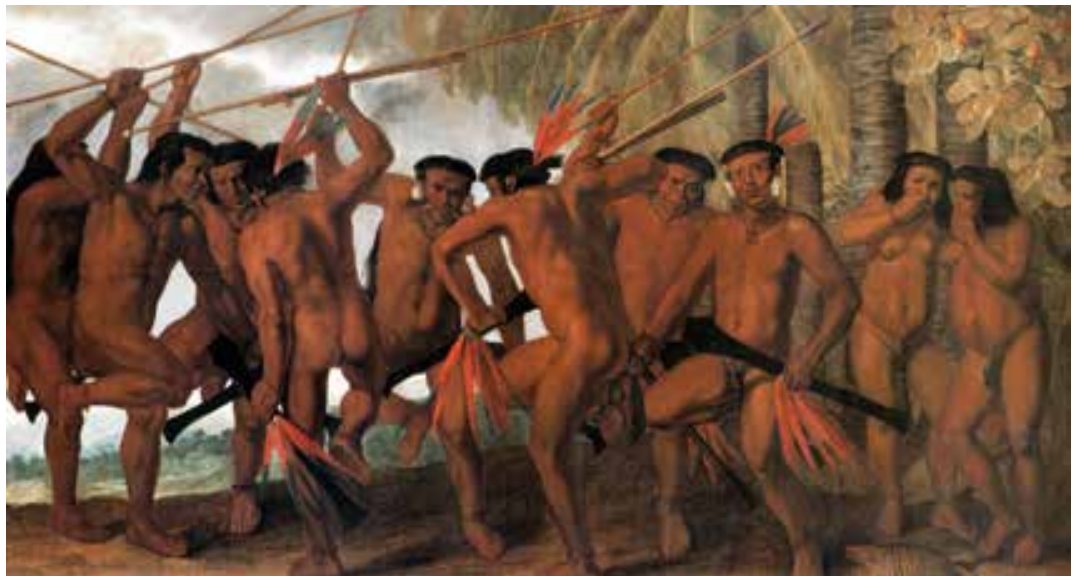

Fonte: Disponível em: https://upload.wikimedia.org/wikipedia/commons/5/54/ Dan\%C3\%A7a_dos_Tapuias.jpg. Acesso em: 21 jul. 2015.

Figura 4: Dança Tapuia, dividida aleatoriamente em duas partes, para ilustrar como a obra costuma aparecer em websites e livros didáticos.
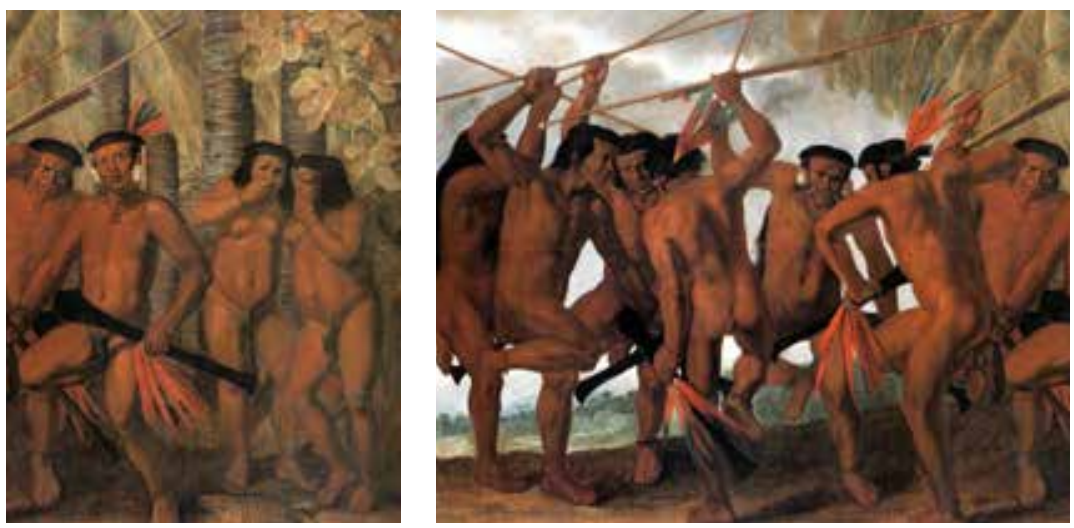

Fonte: Disponível em: https://upload.wikimedia.org/wikipedia/commons/5/54/ Dan\%C3\%A7a_dos_Tapuias.jpg. Acesso em: 21 jul. 2015. 
Para as autoras, foi impactante perceber que, cerca de três anos mais tarde, numa ponta oposta das Américas, historiadores da nova historia indígena usavam o mesmo argumento para demonstrar o que às vezes parece tão difícil de ser entendido, que não se pode ensinar a história das Américas sem a história dos indios.

\section{À guisa de conclusão}

Escrever e ensinar sobre a história dos índios nas Américas não é uma tarefa fácil. Em 1987, Michael Dorris, pesquisador indígena da etnia Modoc, e então diretor do Núcleo de Estudos Indígenas em Dartmouth College, em New Hampshire, apontou caminhos estratégicos para que os pesquisadores pudessem encarar, talvez com maior êxito, esse desafio. Escreveu que uma séria consideração sobre história indígena deve começar com uma "inicial, abrupta e dolorosa 'desmitologização"'. De acordo com a antropóloga Jennifer Brown e a historiadora Elizabeth Vibert, o que Dorris chamou de "desmitologização", alguns estudiosos têm chamado de "descolonização do conhecimento" (BROWN; VIBERT, 2003, p. 12). Descolonizar o conhecimento significa entender melhor o projeto de colonização, ou seja, buscar compreender da maneira mais profunda possível, os contextos históricos específicos em que diversos tipos de narrativas sobre os europeus e o outro foram produzidas. É preciso confrontar a lógica de ideias arraigadas sobre cultura e diferença cultural para romper com o que Daniel Usner considerou um dos legados mais duradouros e enigmáticos do colonialismo, o discurso infeliz que prende os índios entre dois polos opostos, o da autencidade e o da aniquilação e oculta a maneira pela qual sociedades dinamicas e duraveis buscam conciliar tradição e inovação em sua acomodação e resistência diante de forças poderosas (USNER, 2009). Romper com esse discurso na prática do fazer históriografico abre novos caminhos para tornar a presença dos índios menos discreta - que, neste caso, é o mesmo que dizer mais real - no âmbito dos estudos sobre historia social de distintas partes das Américas. 


\section{ONE FLIGHT OVER HISTORIES: ABOUT INDIANS AND HISTO- RIANS IN BRAZIL AND AMERICA}

Abstract: Brazilian and North American historiography share many aspects when it comes to indigenous issues. In both cases, the histories of native groups changed the ways of producing knowledge about them, creating and transforming public policy. Games of complex influences guided the ways of dealing with the knowledge about inter-ethnic relations. In many cases, such knowledge served as a fulcrum for the survival of the implicated groups. Historiographical trajectories, here and there, are full of convergence, divergence, dynamism and political complexity. That said, the purpose of this article is to present a vision of the two parallel processes of construction of historical discourses about Indians and trace from there, agendas and possibilities of mutual contributions.

Keywords: Indians. Brazilian Indigenous History. North American Indian History. Historiography.

\section{Notas}

${ }^{1}$ Segundo Artur Lima de Avila, o processo de instituicionalização da História como disciplina nos EUA está imbricada com a atuação direta de Frederick Jackson Turner e da Western History como motivo temático central, "Em suas mãos, a história do Oeste, ou melhor, da fronteira, era a história dos Estados Unidos" (2006, p. 36). O autor argumenta que Turner fora responsável pela formação de grande parte dos historiadores graduados nos EUA no final do século XIX e início do XX, atuando na Universidade Estadual de Wisconsin até 1910 e em Harvard, posteriormente. A História Americana era fruto de um processo contínuo de ocupação do Atlântico ao Pacífico, "[...] A tese de Turner deu movimento ao espaço nacional, conferindo-lhe uma identidade através deste processo. Os personagens de sua história eram homens e mulheres anônimos, que moviam-se sobre o continente americano, impelidos por um destino que lhes era anterior [o chamado Destino Manifesto]. Do choque dialético entre a selvageria, representada pela natureza indomada, e a civilização, simbolizada pelos colonos, nasceu a excepcional democracia norte-americana. A condição material para o surgimento deste regime politico sem igual eram as chamadas "terras livres" do Oeste, territórios apenas esperando para serem ocupados por seres humanos estóicos e dedicados à árdua labuta na terra. A expansão, contudo, havia chegado ao fim em 1890, quando o Censo Nacional declarou estarem ocupadas todas estas terras livres. O país estava fechado em si mesmo" (2006, p. 37). Para mais informações sobre Turner, fronteira Americana e Destino Manifesto, ver: AVILA, Arthur Lima de. E da Fronteira veio um pioneiro... a frontier thesis de Frederick Jackson Turner (1861-1932). Dissertação (Mestrado). Programa de

Anos 90, Porto Alegre, v. 22, n. 41, p. 173-208, jul. 2015 
Pós-Graduação em História - Departamento de História, UFRGS, Porto Alegre, 2006. Para informações sobre a institucionalização da Antropologia e Etnologia, ver: ERIKSEN, Thomas Hylland; NIELSEN, Finn Sivert. História da Antropologia. Petrópolis: Vozes, 2007.

${ }^{2}$ Para mais informações sobre o Indian Removal Act, consultar: SPENCE, Mark David. Dispossessing the Wilderness: Indian Removal and the Making of the National Parks. Oxford University Press, 2000. Esse livro também traz uma interessante análise sobre a formação dos parques nacionais não tratados neste artigo.

${ }^{3}$ Conforme afirmamos anteriormente, outros grandes massacres podem ser identificados na historiografia Americana: Sacramento river, Moutain Meadows, Marias River, Camp Grant, entre outros. Para mais informações sobre esses eventos, consultar McMurtry, Larry. On what a slaughter. Massacres in the American West: 1846-1890. New York: Simon \& Schuster, 2005.

${ }^{4}$ De maio a outubro de 1893, a cidade de Chicago sediou A Feira Mundial que comemorava os 400 anos da chegada de Colombo a América e colocava os EUA simbolicamente dentro do grupo de países que podiam celebrar e apontar o futuro, apresentando novidades tecnológicas, científicas, gastronômicas e socioculturais. Entre as atrações, o já famoso espetáculo do empresário e artista William Frederick Cody, o Buffalo Bill, O oeste selvagem, destacava-se. Contava com a participação de indígenas de diversos grupos, inclusive a liderança Touro Sentado, bem como atiradores, militares, turcos, mongóis, cossacos, árabes. Em encenações que contavam uma história do Oeste, o espetáculo levou aos EUA e a Europa, aquilo que os intelectuais tentavam resolver: do que era feita a América. Paralelamente à Feira, ocorria um congresso de historiadores no qual Frederick Turner apresentava suas teses sobre a fronteira. Uma excelente análise sobre esse "encontro" é feita por Richard White no ensaio Frederick Jackson Turner and Buffalo Bill. In. The Frontier in American Culture. ed. James R. Grossman. Berkeley: University of California Press, 1994.

${ }^{5}$ JOSEPHY, Alvin M. The Nez Perce and the Opening of the West. Boston: Mariner Books, 1997. BERTHRONG, Donald J. The Cheyenne and Arapabo Ordeal: Reservation and Agency Life in the Indian Territory, 1875-1907. London: University of Oklahoma Press, 1992.

${ }^{6}$ A autora concentra seu trabalho no sul dos Estados Unidos (Lousiana e Alabama), onde os embates raciais eram claramente polarizados entre brancos e negros. Uma das principais críticas coladas na época e de consequências permanentes, é que as questões raciais nos EUA tenderam a respostas negras, para problemas e demandas que eram muito mais diversas.

${ }^{7}$ Para mais informações sobre as conecções entre os movimentos de contracultura e as questões indígenas, consultar: SMITH, Sherry L. Hippies, Indians \& the figth for Red Power. New York: Oxford University Press, 2012.

Anos 90, Porto Alegre, v. 22, n. 41, p. 173-208, jul. 2015 
${ }^{8}$ Segue uma lista com algumas obras dos autores mencionados que não puderam ser tratadas no corpo do artigo: AXTELL, James. The invasion within: the contest of cultures in Colonial North America. New York: Oxford University Press, 1985.; Natives and newcomers: the cultural origins of North America. New York: Oxford University Press, 2001; DOWD, Gregory E. A spirited resistance the North American Indian struggle for unity, 1745-1815. Baltimore: Johns Hopkins University Press, 1992; EDMUNDS, R. David. Tecumseh and the Quest for Indian Leadership. Boston: Little, Brown, 1984; O’BRIEN, Jean M. After King Philip's War: presence and persistence in Indian New England. Hanover University Press of New England, 1997; RICHTER, Daniel. The Ordeal of the Longhouse: The Peoples of the Iroquois League in the Era of European Colonization. Chapel Hill: University of North Carolina Press, 1992; PERDUE, Theda. Cherokee women: gender and culture change, 1700-1835. Lincoln: University of Nebraska Press, 1998.

${ }^{9}$ A publicação, em 2011, de Native historians write back: decolonizing American Indian history, reunindo ensaios e artigos de autores nativos de distintos grupos sintetiza como as perspectivas nativas podem apontar para caminhos renovadores da história americana. MILLER, Susan A; RIDING, James (Org.). Native bistorians write back: decolonizing American Indian history. Lubbock: Texas Tech University Press, 2011.

${ }^{10}$ Todas as impressões sobre este evento são fruto dos entendimentos das autoras que tiveram a oportunidade de participar do mesmo como pesquisadoras associadas à Newberry Library naquele momento. A imagem do cartaz do evento encontra-se disponível em: http:/ /www.newberry.org/past-american-indian-studies-seminars. Acesso em: 15 set. 2014.

${ }^{11}$ Para mais informações sobre o IHGB, consultar SCHWARCZ, Lilia Katri Moritz. Os Institutos Históricos e Geográficos. Os guardiões de nossa bistória oficial. São Paulo: Editora Vértice/Idesp, 1989.

${ }^{12}$ Para mais informações sobre o tema da Lei de Terras, ver SILVA, Lígia Osório. Terras Devolutas e Latifúndio. Campinas: Editora da Unicamp, 2008. Embora a autora concentre-se no processo paulista, pode-se ter uma visão geral do processo em termos judiciais e de direitos sobre terras dos índios.

${ }^{13}$ OTTONI, Teófilo Benedito; OTTONI, Honório Benedito. Condições para Incorporação de uma Companbia de Comércio e Navegaşão do Rio Mucuri, precedidas de uma exposição das vantagens da empresa. Rio de Janeiro: Tipografia Imperial e Constitucional de J. Velleneuve e Companhia, 1847; - Notícia Sobre os Selvagens do Mucuri. DUARTE, Regina Horta (Org.). Belo Horizonte: Editora UFMG, 2002;

Circular dedicada aos Srs. Eleitores de senadores pela provincia de Minas Gerais no quadriênio atual e especialmente dirigida aos Srs. eleitores de deputados pelo $2^{\circ}$ distrito eleitoral da mesma Provincia para a próxima legislatura. Revista do Instituto Histórico e Geográfico Brasileiro. Tomo LXXVIII, Parte 2. Rio de Janeiro, 1916; - A Colonização 
do Mucuri. Rio de Janeiro: Tipografia Brasiliense de Maximiano Gomes Ribeiro, 1859. In: ARAUJO, Valdei Lopes de (Org.). Teófilo Benedito Ottoni e a Companbia do Mucuri: a modernidade possível. Belo Horizonte: Secretaria de Estado da Cultura; Arquivo Público Mineiro, 2007; . Companbia do Mucuri. História da empresa, importancia de seus privilégios, alcance dos seus projetos. Rio de Janeiro: Tipografia Imperial e Constitucional de J. Villeneuve e Companhia, 1856. In.: ARAUJO, Valdei Lopes de (Org.). Teófilo Benedito Ottoni e a Companbia do Mucuri: a modernidade possível. Belo Horizonte: Secretaria de Estado da Cultura; Arquivo Público Mineiro, 2007;

Breve Resposta ao Relatório de Liquidação da Cia. do Mucuri, porparte do Governo. Rio de Janeiro: Tip. de M. Barreto, Mendes Campos e Comp., 1862; Discursos Parlamentares. Seleção e introdução de Paulo Pinheiro Chagas. Brasília: Câmara dos Deputados, 1979. Relatório apresentado aos acionistas da Companbia do Mucuri por Teófilo Benedito Ottoni em 15 de outubro de 1857. Rio de Janeiro: Tipografia Imperial e Constitucional de J. Villeneuve e Companhia, 1857. (Coleção Assuntos Mineiros). In. ARAUJO, Valdei Lopes de (Org.). Teófilo Benedito Ottoni e a Companbia do Mucuri: a modernidade possível. Belo Horizonte: Secretaria de Estado da Cultura; Arquivo Público Mineiro, 2007; . Relatório apresentado aos acionistas da Companbia do Mucuri no dia 15 de maio de 1860. Rio de Janeiro: Tipografia do Correio Mercantil, 1860. (Coleção Assuntos Mineiros) In. ARAUJO, Valdei Lopes de (Org.). Teófilo Benedito Ottoni e a Companbia do Mucuri: a modernidade possível. Belo Horizonte: Secretaria de Estado da Cultura; Arquivo Público Mineiro, 2007.

${ }^{14}$ ANDRADE, Osvald de. O Manifesto Antropofágico. Disponível em http:// serantropofagia.wordpress.com/about/. Acesso em: 15 set. 2014.

${ }^{15}$ Curt Unckel foi naturalizado brasileiro e batizado pelos Guarani-Ñandeva com o nome Nimuendajú, aquele que faz a sua morada, em tupi-guarani.

${ }^{16}$ AMOROSO, Marta Rosa. Nimuendajú às voltas com a história. Revista de Antropologia, São Paulo: USP, 2001, v. 44, n. 2. Disponível em http://www.ifch. unicamp.br/ihb/HZ868-06/MartaNimuendajuRA.pdf. Acesso em: 22 out. 2014. ${ }^{17}$ Para mais informações, FREIRE, Carlos Augusto da Rocha (Org.). Memória do SPI. Textos, imagens e documentos sobre o serviço de proteção aos indios (1919-1967). Rio de Janeiro: Museu do Índio-FUNAI, 2011.

${ }^{18}$ O Índios Kaingang no Rio Grande do Sul. Pesquisas, Antropologia, n. 29, 1976. ${ }^{19}$ A história de criação do Guia de Fontes mescla-se com a do Núcleo de Pesquisas da História dos Índios e do Indigenismo da USP. Manuela Carneiro da Cunha coordenava um projeto interinstitucional e interdisciplinar na tentativa de elaborar um Guia para o campo em crescimento aos moldes do Guia de fontes para a história da Africa, da escravidão negra e do negro na sociedade atual, publicado pelo Arquivo Nacional em 1988, centenário da abolição. Por razões diversas, o projeto não se concretizou por essas vias, mas deu origem ao Núcleo (MONTEIRO, 1994, p. 07-08).

Anos 90, Porto Alegre, v. 22, n. 41, p. 173-208, jul. 2015 
${ }^{20}$ John Manuel Monteiro lecionou na UNESP (Araraquara, Assis e Franca) entre 1986 e 1991, e na Universidade Estadual de Campinas (UNICAMP) desde 1994, vinculado tanto ao Departamento de Antropologia quanto ao de História. Foi professor visitante na Harvard University (2003-2004), University of Michigan (1997) e University of North Carolina-Chapel Hill (1985-1986). Além de sua experiência como docente, foi "Directeur d'Études Invité", na EHESS, em Paris (1999) e pesquisador do CEBRAP de 1991 a 1998. Sua atuação junto à Associação Brasileira de Antropologia (ABA), a Associação Nacional de História (ANPUH) e a Associação Nacional de Pós-Graduação e Pesquisa em Ciências Sociais (ANPOCS) são demonstrativos de sua circulação e abertura para diálogo e articulação. Era também coordenador do Grupo de Trabalho sobre temática indígena na ANPUH que reunia pesquisadores de todo o país. John Monteiro faleceu em março de 2013, aos 56 anos, em um acidente de trânsito.

${ }^{21}$ Felizmente, por os índios terem se tornado tema de estudo de um grande e eficiente grupo de historiadores e antropólogos, este artigo não poderá contemplar a totalidade de trabalhos antigos e novos produzidos após a década de 1990. Nosso critério foi priorizar os estudos publicados ou aqueles que se destacaram em temáticas específicas. Uma relação praticamente completa pode ser encontrada no site criado por John Monteiro, Os Índios na História do Brasil. Informacõoes, estudos, imagens. Ali, além das indicações, são apresentadas resenhas dos trabalhos. Disponível em http://www.ifch.unicamp.br/ihb/. Acesso em: 15 set. 2014.

${ }^{22}$ John Monteiro realizou a conferência de encerramento do I Fórum Internacional da Temática Indígena, a convite das autoras deste artigo, também idealizadoras e organizadoras do referido evento.

\section{Referências}

ALMEIDA, Maria Regina Celestino de. Metamorfoses indigenas: identidade e cultura nas aldeias coloniais do Rio de Janeiro. Rio de Janeiro: Arquivo Nacional, 2003.

AVILA, Arthur Lima de. Território Contestado: a reescrita da história do Oeste norte-americano (c. 1985-c. 1995). Tese (Doutorado). Programa de Pós-Graduação em História - UFRGS, Porto Alegre, 2010.

. E da Fronteira veio um pioneiro... a frontier thesis de Frederick Jackson Turner

(1861-1932). Dissertação (Mestrado). Programa de Pós-Graduação em História - UFRGS, Porto Alegre, 2006.

AXTELL, James. Ethnohistory: An Historian's Viewpoint. Ethnohistory, v. 26, n. 1, 1979, p.1-13.

Anos 90, Porto Alegre, v. 22, n. 41, p. 173-208, jul. 2015 
AXTELL, James. The invasion within: the contest of cultures in Colonial North America. New York: Oxford University Press, 1985.

. Natives and newcomers: the cultural origins of North America. New York:

Oxford University Press, 2001

BARNES, Ian. The Historical Atlas of Native Americans. New York: Chartwell Books, 2010.

BATES, Denise E. The Other Movement: Indian Rights and Civil Rights in the Deep South. Alabama: The University of Alabama Press, 2012.

BLACKHAWK, Ned. Look how far we've come: how American Indian History changed the study of American History in the 1990s. OAH Magazine of History. v. 19, n. 6, American West, Nov., 2005, p. 13-17.

BRIENEN, Rebecca Parker. Visions of Savage Paradise: Albert Eckhout, Court Painter in Colonial Dutch Brazil. Amsterdam: Amsterdam Press, 2006.

BROWN, Dee. Bury My Heart at Wounded Knee; an Indian history of the American West. New York: Holt, Rinehart \& Winston, 1971.

BROWN, Jennifer S. H.; VIBERT, Elizabeth. Reading beyond words: contexts for native history. Canada: Broadview Press Ltd, 2003.

CALLOWAY, Colin G. New worlds for all: Indians, Europeans, and the remaking of early America. Baltimore: Johns Hopkins University Press, 1997.

CARVALHO Jr., Almir Diniz de. Índios cristãos: a conversão dos gentios na Amazônia portuguesa (1653-1769). Doutorado (Tese) Campinas, 2005.

CAVENAGHI, A. J. Uma guerra, dois mapas e duas fotografias. O Sertão do Noroeste Paulista e a aventura do registro iconográfico ao final do século XIX. Revista Projeto História. São Paulo, n. 32, p. 191-219, jun. 2006.

CUNHA, Manuela Carneiro da. Política Indigenista no século XIX. In. História dos indios no Brasil. São Paulo: Companhia das Letras, 1992.

DEBO, Angie. And still the Waters Run. The betrayal of the five civilized tribes. New Jersey: Princeton University Press, [1940] 1968.

DELORIA Jr., Vine. Custer Died for Your Sins: An Indian Manifesto. New York: Macmillan, [1969] 1988.

ERIKSEN, Thomas Hylland; NIELSEN, Finn Sivert. História da Antropologia. Petrópolis: Vozes, 2007.

FREITAS, Edinaldo Bezerra de. A construção do imaginário nacional: entre representações e ocultamentos. As populações indígenas e a historiografia. Revista Labirinto. 2000. Disponível em: http://www.cei.unir.br/artigo103.html. Acesso em: 02 out. 2014.

Anos 90, Porto Alegre, v. 22, n. 41, p. 173-208, jul. 2015 
HÄMÄLÄINEN, Pekka. The Futures of Native American History in the United States. In: Perspectives on History. The Newmagazine of American Historical Association. Dezembro de 2012. Disponível em: http://www.historians.org/publications-anddirectories/perspectives-on-history/december-2012/the-future-of-the-discipline/ the-futures-of-native-american-history-in-the-united-states. Acesso em: 03 set. 2014.

KOK, Glória. O Sertão Itinerante: expedições da Capitania de São Paulo no Século XVIII. São Paulo: Hucitec, 2004.

MARTIUS, Carl Friedrich Phillip von. O Estado de Direito entre os autóctones do Brasil. Belo Horizonte: Itatiaia, 1982.

McDONNELL, Janet A. The Dispossession of the American Indian, 1887-1934. Bloomington: Indiana University Press, 1991.

MERRILL, James. The Indians' New World: Catawbas and Their Neighbors from European Contact through the Era of Removal. Williamsburg: University of North Carolina Press, 1989

MONTEIRO, John Manuel. Negros da terra: indios e bandeirantes nas origens de São Paulo. São Paulo: Companhia das Letras, 1994.

. Tupis, tapuias e historiadores. Estudos de história indígena e do indigenismo. Tese apresentada para o concurso de Livre Docência em Antropologia na Universidade Estadual de Campinas. Campinas, 2001.

MORGAN, Lewis Henry. League of the Hode 'nosannee, or Iroquois. vol. 2. Rochester/ New York, 1851; rept. New York: Dodd, Mead, 1901, p. 10813. Disponível em: http://www.fordham.edu/halsall/mod/1851morgan.asp. Acesso em 03 set. 2014.

O'BRIEN, Jean M. After King Philip's War: presence and persistence in Indian New England. Hanover University Press of New England, 1997.

POMPA, Cristina. Religião Como Tradução: missionários, Tupi e Tapuia no Brasil colonial. Bauru: EDUSC, 2003.

PUNTONI, Pedro. A Guerra dos barbarous: povos indígenas e a colonização do sertão nordeste do Brasil, 1650-1720. São Paulo: Hucitec/Edusp, 2002.

SHEPHERD, Jeffrey P. From Savages to Sovereigns: A General Historiography of American Indian History. University of Texas at El Paso. s/d. Disponível em: https:/ / www.google.com.br/urlsa $=$ t\&rct $=j \& q=\& e s r c=$ s\&source $=$ web\&cd $=$ $1 \& \mathrm{cad}=$ rja\&uact $=8 \& \mathrm{ved}=0 \mathrm{CB} 0 \mathrm{QFjAA} \& u r l=$ https $\% 3 \mathrm{~A} \% 2 \mathrm{~F} \% 2 \mathrm{~F}$ faculty.utep. edu $\% \% 2$ FI. Acesso em: 15 set. 2014.

SMITH, Sherry L. Hippies, Indians \& the figth for Red Power. New York: Oxford University Press, 2012.

Anos 90, Porto Alegre, v. 22, n. 41, p. 173-208, jul. 2015 
Sobrevoando histórias: sobre índios e historiadores no Brasil...

SPENCE, Mark David. Dispossessing the Wilderness: Indian Removal and the Making of the National Parks. Oxford University Press, 2000.

USNER, Daniel H. Indian Work: Language and Livelihood in Native American History.Cambridge: Harvard University Press, 2009.

VAINFAS, Ronaldo. A Heresia dos Índios. Catolicismo e Rebeldia no Brasil Colonial. ( São Paulo: Companhia das Letras, 1995.

WHITE, Richard. The roots of dependency: subsistence, environment, and social change among the Choctaws, Pawnees, and Navajos. Lincoln: University of Nebraska Press, 1983.

. The Middle Ground: Indians, Empires, and Republics in the Great Lakes Region, 1650-1815. New York: Cambridge University Press, 1991.

. Frederick Jackson Turner and Buffalo Bill. In. WHITE, R., LIMERICK, P. The Frontier in American Culture. An exbibition at the Newberry Library, August 26, 1994-January 7, 1995. Barkeley, Los Angeles, London: University of California Press, 1994. p. 07-66.

WITTMANN, Luisa Tombini. O Vapor e o Botoque: imigrantes alemães e índios Xokleng no Vale do Itajaí/SC (1850-1926). Florianópolis: Letras Contemporâneas, 2007.

Recebido em: 31/10/2014

Aprovado em: 18/05/2015 